УДК 355.724

Михайло Григорович Лозовий ${ }^{1}$

Олег Михайлович Воробйов (доктор технічних наук, професор) ${ }^{1}$

Ігор Олександрович Власов (кандидат військових наук, доцент) ${ }^{1}$

Микола Миколайович Чапля (кандидат медичних наук) ${ }^{2}$

${ }^{1}$ Національний університет оборони Украӥни імені Івана Черняховського, Київ, Украӥна

${ }^{2}$ Медичний реабілітаційний центр МВС Украӥни “Перлина Прикарпаття”, Трускавець, Украӥна

\title{
ДОСВІД ОРГАНІЗАЦІЇ МЕДИЧНОГО ЗАБЕЗПЕЧЕННЯ ВІЙСЬК (СИЛ) В ОПЕРАЦІЇ ОБ`ЄДНАННИХ СИЛ
}

Вивчення особливостей роботи медичної служби Збройних Сил Украӥни щзодо планування, організації та реалізації медичного забезпечення в мирний та воєнний час в різноманітних умовах $\epsilon$ пріоритетним напрямком ї̈ діяльності. Відповідно вимогам керівних документів медичне забезпечення військ (сил) повинно бути організовано в будь яких умовах діяльності військ (сил): як при веденні бойових дій, так $і$ в умовах повсякденної діяльності військ.) В умовах сучасної гібридної війни на організацію медичного забезпечення військ (сил) впливають фактори оперативної, бойової, медичної та тилової обстановки. Тому для планування медичного забезпечення військ (сил) в Операиії об'єднаних сил (АТО) необхідно ичі фактори вивчити, проаналізувати їх вплив на організацію медичного забезпечення, зробити висновки $i$ на їx підставі прийняти рімення на організацію медичного забезпечення. $B$ статті розглядаються питання, щзо стосуються факторів, які впливають на організачію медичного забезпечення військових частин $і$ з'єднань, загальних принципів застосування сил медичної служби в ООС (АТО), особливостей їх застосування в різни періоди операції.

Метою даної статті є вивчення умов діяльності медичної служби під час проведення ООС (АТО), загальних принципів $i$ способів застосування сил $i$ засобів медичної служби ЗС Украӥни під час проведення ООС. Автори розглядають порядок(варіанти) використання прийомів скорочення часу для надання першої лікарської, кваліфікованої та спеціалізованої медичної допомоги шляхом створення нових медичних формувань (підрозділів), які раніше не були передбачені, а також інтеграційними процесами в систему цивільної охорони здоров'я Визначається, шчо вказані шляхи використання сил засобів медичної служби як МО України, так і МОЗ України суттєво скорочують терміни надання периої лікарської, кваліфікованої та спеціалізованої медичної допомоги військовослужбовиям ЗС Украӥни.

Ключові слова: медичне забезпечення, лікувально-евакуачійні заходи, вид медичної допомоги, військовий мобільний госпіталь, цивільна охорона здоров'я, кваліфікована медична допомога.

\section{Вступ}

В умовах особливого періоду в країні, коли продовження бойових дій на сході України, періодичних загострень і розширення військового протистояння супроводжується появою поранених (уражених, хворих), виникає необхідність надання ім своєчасної медичної допомоги, повноцінного лікування та медичної реабілітації 3 метою відновлення їх боєздатності і працездатності. Актуальним питанням в системі організації лікувально-евакуаційного забезпечення в ході бойових дій завжди залишається реалізація принципу своєчасного надання відповідного виду медичної допомоги пораненим і хворим військовослужбовцям.

Вирішення цього питання за досвідом організації медичного забезпечення в локальних війнах i збройних конфліктах сучасності здійснювалось різними способами, у тому числі і різноманітними варіантами застосування сил i засобів медичної служби. Вивчення форм i способів застосування сил i засобів медичної служби в ході проведення операції Об'єднаних сил (ООС) дозволяє удосконалити реалізацію принципу своєчасності в наданні певного виду медичної допомоги пораненим i хворим військовослужбовцям та втілити його в бойову практику медичної служби.
Постановка проблеми. Аналіз організації лікувально-евакуаційного забезпечення бойових дій в зоні ООС за перші місяці представниками Світового конгресу Українців свідчіть, що кваліфікована медична допомога пораненим надавалася через 16-36 годин, а у серпні 2014 року-через 4-24 години, тобто перевищувала терміни надання в 2-3 рази. Причини - відсутність своєчасної евакуації 3 поля бою до установ надання кваліфікованої медичної допомоги; використання лише автомобілів для евакуації при недостатньої кількості повітряних засобів; відсутність сил і засобів медичної служби спроможних надавати кваліфіковану медичну допомогу і наближених до переднього краю та ін. Починаючи 3 5-6 години після поранення, незалежно від якості кваліфікованої хірургічної допомоги, що надається, інтенсивність збільшення смертності та інвалідності й кількість тих, що не повертаються у стрій, зростає [1]

Тому вирішення питання скорочення термінів надання усіх видів медичної допомоги $\epsilon$ актуальною проблемою воєнної медицини в локальних війнах та збройних конфліктах.

Аналіз останніх досліджень і публікацій свідчить про необхідність суттєвого перегляду концепції організації лікувально-евакуаційних заходів в ході збройних конфліктів і локальних 
війн, особливо в їх підготовчий i начальний період.

В останні роки визначено, що існуючий стан медичного забезпечення Збройних Сил України не відповідає реальним потребам військ (сил) як повсякденній діяльності, так i під час їx застосування(у тому числі й в ході ООС), а також сучасним вимогам щодо медичного забезпечення військ держав-членів НАТО. Визначені основні системні проблеми медичного забезпечення, серед яких невідповідність організаційно-штатної структури медичної служби ЗС України завданням та сучасній тактиці застосування військ (сил), а також відсутність достатньої кількості підготовленого персоналу для комплектування медичних підрозділів військових частин і з'єднань, військово-медичних закладів [2].

Вагомий внесок у розвиток системи лікувально-евакуаційного забезпечення внесли керівні документи та роботи [3-5]. У них обгрунтована необхідність концептуального перегляду системи лікувально-евакуаційних заходів, особливо своєчасності надання медичної допомоги, яка реалізується шляхом дотримання вимог принципу 10-1-2, що означає надання домедичної допомоги не пізніше 10 хвилин після поранення, надання першої лікарської допомоги протягом однієї години та невідкладних заходів кваліфікованої (першої хірургічної) допомоги не пізніше двох годин з моменту поранення.

У роботі [6] автори визначають необхідність прискорення інтеграційних процесів складових загальнодержавної системи охорони здоров'я 3 метою створення єдиного медичного простору держави.

Роботи [7,8] присвячені розгляду сучасних тенденцій надання медичної допомоги пораненим i хворим в ході збройних конфліктів різної інтенсивності (у тому числі в ООС)) і локальних війнах. Однак в них в недостатній мірі розглядаються питання надання певних видів медичної допомоги в умовах ООС.

Метою статті $є$ розгляд застосування способів удосконалення надання певних видів медичної допомоги в умовах ООС, перегляд концептуальних підходів до організації лікувально -евакуаційних заходів за досвідом організації медичного забезпечення в локальних війнах i збройних конфліктах.

\section{Виклад основного матеріалу дослідження}

Медичне забезпечення $\epsilon$ окремим видом забезпечення Збройних Сил України і являє собою систему заходів, щодо збереження та зміцнення здоров'я особового складу, запобігання виникненню і розповсюдженню хвороби, надання медичної допомоги військовослужбовцям, лікування i відновлення їх працездатності та боєздатності після поранень, захворювань і травм.

Медичне забезпечення включає організаційні, лікувально-евакуаційні, санітарно-гігієнічні та протиепідемічні заходи, медичне постачання, підготовку військово-медичних кадрів i наукове вирішення проблем військової медицини.

Основою медичного забезпечення військ у воєнний час $\epsilon$ система лікувально-евакуаційних заходів, яка передбачає організацію надання медичної допомоги пораненим, ураженим, постраждалим та хворим. Лікувально-евакуаційні заходи включають розшук, збір та винос (вивіз) поранених 3 поля бою або вогнищ масових санітарних втрат, надання їм необхідних видів медичної допомоги, евакуацію, лікування та медичну реабілітацію. Сутність сучасної системи лікувально-евакуаційних заходів полягає в етапному лікуванні поранених 3 їх евакуацією за призначенням 3 використанням медичних підрозділів військових частин, мобільних i стаціонарних військово-медичних закладів та максимальним залученням існуючої мережі цивільних закладів охорони здоров'я [7].

На організацію медичного забезпечення військових частин (з'єднань) в антитерористичній операції впливають склад оперативного угруповання військ (сил), поєднання різних видів бойових дій стабілізаційні, оборонні, наступальні бойові діiі) під час проведення антитерористичної операції; активність оборони 3 широким застосуванням маневру військ i нанесенням контрударів, відсутність єдиного фронту та глибокого ешелонування бойових порядків; використання цивільних закладів охорони здоров'я як етапів медичної евакуації; постійна загроза проведення диверсій, терористичних актів на етапах медичної евакуації; загроза виникнення осередків масових санітарних втрат серед цивільного населення внаслідок терористичних актів на об'єктах інфраструктури, небезпечних об'єктах з виникненням хімічного, біологічного та радіаційного забруднення; необхідність ретельного проведення санітарно-гігієнічних та протиепідемічних заходів у разі відносно тривалого перебування військ в обороні.

Загальними принципами медичного забезпечення військ (сил) в антитерористичній операції є: організація якнайшвидшого розшуку, виносу поранених та хворих та їх вивозу 3 осередку виникнення санітарних втрат; наближення сил та засобів медичної служби до військ (сил), що забезпечуються, 3 метою найшвидшого проведення лікувальноевакуаційних, санітарно-гігієнічних i протиепідемічних заходів; скорочення обсягу медичної допомоги, особливо на етапах медичної евакуації, що знаходяться на напрямку ймовірного удару противника, і швидка евакуація поранених та хворих з районів, що знаходяться під загрозою захоплення (оточення) противником; надання допомоги медичній службі військових частин (з'єднань) шляхом маневру в їх інтересах i підсилення відповідними силами та засобами старшого начальника медичної служби; постійна готовність етапів медичної евакуації до переміщення разом з пораненими і хворими на запасні площадки; постійна готовність сил та засобів медичної служби до здійснення лікувально-евакуаційних заходів під час ліквідації наслідків застосування противником засобів масового ураження, організації i своєчасного проведення ефективних заходів медичної служби щодо захисту особового складу військ, етапів медичної евакуації від зброї масового ураження та від хімічних, біологічних та радіаційних чинників під час руйнування небезпечних об'єктів промисловості.

Під час підготовки до проведення 
антитерористичної операції угруповання сил i засобів медичної служби створюються відповідно до оперативної побудови (бойового порядку) оперативного угруповання військ (сил).

У цей період проводиться планування медичного забезпечення військ (сил), ставляться завдання підлеглим, здійснюється підготовка сил і засобів медичної служби та проводяться необхідні заходи медичної служби серед особового складу військ (сил).

Підготовка медичної служби до проведення операції включає: планування медичного забезпечення військ (сил), уточнення і постановку завдань підрозділам, частинам та закладам медичної служби; евакуацію поранених та хворих iз підрозділів та закладів медичної служби; розгортання медичних пунктів батальйонів, медичних рот бригад, військових мобільних госпіталів у визначених районах залежно від характеру у майбутніх бойових дій військ (сил); доукомплектування підрозділів (частин, закладів) медичної служби особовим складом і транспортом; підсилення силами та засобами медичної служби цивільних лікувальних закладів, що будуть використовуватися як етап медичної евакуації; поповнення витрат медичного майна, створення необхідних його запасів; забезпечення особового складу військ індивідуальними засобами медичного захисту та навчання правилам користування ними; створення необхідного резерву сил та засобів медичної служби; організацію i проведення медичної розвідки; організацію і проведення необхідних санітарногігієнічних та протиепідемічних заходів; проведення заходів щодо захисту сил та засобів медичної служби від засобів ураження противника, організації їх охорони та оборони; проведення занять 3 військово-медичної підготовки з особовим складом військових частин і спеціальної підготовки 3 особовим складом медичної служби.

У Збройних Силах України в процесі проведення лікувально-евакуаційних заходів в особливий період i в ході ООС передбачалось надання першої медичної (домедичної) допомоги, долікарської (фельдшерської) допомоги, першої лікарської допомоги, кваліфікованої медичної допомоги, спеціалізованої високоспеціалізованої медичної допомоги та медичної реабілітації. Вид медичної допомоги - це певний перелік (комплекс) лікувальнодіагностичних та лікувально-евакуаційних заходів, що проводяться при пораненнях i захворюваннях особовим складом військ та медичною службою на полі бою, в осередках санітарних втрат і на етапах медичної евакуації [7].

Медична допомога та лікування поранених, уражених і хворих повинна надаватись на етапах медичної евакуації, які формуються за рахунок медичних пунктів військових частин (підрозділів), медичних рот бригад та військових мобільних госпіталів, що розгортаються в певній послідовності на евакуаційних напрямках, а також стаціонарних військових або цивільних закладів охорони здоров'я.

Дослідження останніх років переконливо доводять, що в збереженні життя пораненого першочергове значення мають найпростіші, але необхідні й достатні заходи, які здійснюються протягом 30 хвилин після поранення. Від них значною мірою залежить також запобігання ускладненням та інвалідності й імовірність повернення поранених до строю. А ці показники сприяють поповненню особовим складом військових частин і з'єднань, що зазнали втрат у бойових діях, отже, відновленню їх боєздатності.

Іншим, не менш важливим, пріоритетом $\epsilon$ своєчасне надання пораненим (постраждалим) невідкладної, ранньої кваліфікованої та спеціалізованої медичної допомоги. Згідно с сучасними вимогами до медичного забезпечення населення за надзвичайних ситуацій, своєчасною вважається медична допомога, що надається після ураження протягом термінів, які тривають: перша допомога - до 30 хв, долікарська - 1-2 год, перша лікарська 4-6 год, кваліфікована - 8-12 год, спеціалізована -до 24 год [2].

Бойові дії в ході антитерористичної операції велись переважно ротними та батальйонними тактичними групами. Медична служба роти була представлена санітарним інструктором, якій на оснащенні мав сумку медичну військову, розраховану на надання першої медичної допомоги 30 пораненим, а також 2 лямки медичні носильні, лямку медичну спеціальну, ключ для відкриття люків БМП, тобто на рівні ротної ланки передбачалось надання першої медичної допомоги самими військовослужбовцями у порядку самодопомоги та взаємодопомоги, а також молодшим медичним складом - стрільцямисанітарами взводів під керівництвом санітарного інструктора роти, а також нештатними санітараминосильниками.

Медична служба батальйону була представлена начальником МПБ - фельдшером або лікарем, санітарним інструктором, санітарами, водіями санітарами тощо. Усього 9 осіб. На оснащенні передбачалось мати 4 санітарних автомобіля УАЗ3962 та іншу техніку. Така структура медичної служби батальйонної ланки дозволяла надавати долікарську (фельдшерську) допомогу або елементи першої лікарської допомоги, якщо МПБ очолював лікар.

В подальшому першу лікарську допомогу передбачалось надавати в медичних пунктах частин, які очолювали лікарі загальної практики (медичні пункти полків, артилерійських бригад, окремих частин), першу лікарську допомогу 3 невідкладними заходами кваліфікованої медичної допомоги передбачалось надавати в медичних ротах бригад, військових мобільних і стаціонарних госпіталях.

Закінчення надання кваліфікованої медичної допомоги та надання спеціалізованої медичної допомоги - у військово-мобільних і стаціонарних госпіталях, військово-медичних клінічних центрах ГВКГ. Так концептуально будувалась система лікувально-евакуаційного забезпечення військ (сил) на початку антитерористичної операції.

У результаті невідповідності організаційноштатної структури медичної служби Збройних Сил України завданням та сучасній тактиці застосування військ (сил), відсутності достатньої кількості підготовленого персоналу для комплектування медичних підрозділів військових частин і з'єднань, військово-медичних закладів, відсутності сучасного комплектно-табельного Modern Information Technologies in the Sphere of Security and Defence № 1(40)/2021 ISSN 2311-7249(Print)/ISSN 2410-7336(Onine) 71 
оснащення для надання медичної допомоги та низький рівень матеріально-технічного забезпечення медичних підрозділів військових частин i 3'єднань та мобільних військовомедичних закладів (відсутність сучасного санітарно-технічного обладнання, модулів, наметового фонду засобів зв'язку тощо), досвіду організації медичної допомоги пораненим i хворим в ході ООС, а також відповідності вимогам держав-членів НАТО щодо медичного забезпечення військ(сил), концепція організації лікувально-евакуаційних заходів була переглянута [2].

3 початком антитерористичної операції кваліфікована медична допомога пораненим надавалася через 16-36 годин, а у серпні 2014 року - через 4-24 години, тобто перевищувала терміни надання в 2-3 рази. Причина - відсутня евакуація 3 поля бою до установ надання кваліфікованої медичної допомоги, використання лише автомобілів до евакуації, недостатня передова шпитальна база, слабка та застаріла їх матеріальна база, недостатньо повітряних засобів евакуації [8]. У судово-медичній практиці випадки ненадання своєчасної медичної допомоги частіше виникають через значну кровотечу, шок, черепно-мозкову травму та механічну асфіксію. Ці стани $\epsilon$ головними причинами смерті поранених на ТВД та в осередку катастрофи. Але їх зазвичай списують на складність оперативної обстановки або на брак медичних ресурсів там, де в них виникає непередбачена потреба. Так фактично виправдовується смерть тисяч бійців (постраждалих) через недосконалу систему лікувально-евакуаційного забезпечення та недоліки в організації медичної допомоги лікувально-евакуаційного забезпечення та недоліки в організації медичної допомоги [5].

В ході ООС для надання кваліфікованої хірургічної допомоги (переважно невідкладних заходів) за рахунок військових мобільних госпіталів створювались мобільні лікарськосестринськи бригади у складі лікаря-хірурга, лікаря-анестезіолога, операційної сестри, медсестри-анестезистки, молодшого медичного персоналу і були оснащені АП-2, автомобільним санітарним транспортом. Вказані формування використовували для підсилення батальйонних тактичних груп, що давало можливість надавати першу лікарську і елементи кваліфікованої хірургічної допомоги на рівні батальйону.

Аналогічні спосіб застосування сил і засобів медичної служби відносилися i до ротних тактичних груп - вони підсилювались лікарями загальної практики, які мали на оснащенні медичне майно, розраховане для надання першої лікарської допомоги пораненим і хворим.

Тобто, в ході начального періоду антитерористичної операції з метою найшвидшого проведення лікувально-евакуаційних заходів i скорочення термінів надання першої лікарської та кваліфікованої медичної допомоги використовувався принцип наближення сил та засобів медичної служби до військ (сил), що забезпечуються(рис 1).

Таким способом застосування сил ї засобів медичної служби було значно скорочений час надання кваліфікованої хірургічної допомоги: 3 16-36 годин у перши місяці та 14-24 години у серпні 2014 року [8] до від 1,5 - 6 годин до 12 один у наступні періоди операції (рис 2).

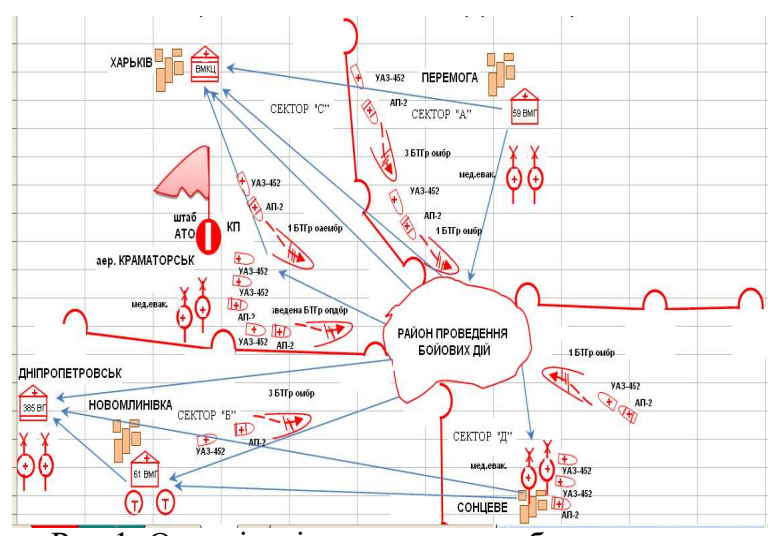

Рис 1. Організація медичного забезпечення на тактичному рівні в зоні АТО



Рис.2. Лікувальне забезпечення в ході начального періоду антитерористичної операції

Основними етапами надання кваліфікованої хірургічної допомоги в системі лікувальноевакуаційного забезпечення військ в початковий період i в ході антитерористичної операції передбачались медичні роти бригад (передові хірургічні групи, які розгортаються самостійно в польових умовах, на базі цивільних закладів охорони здоров'я або на тактичному рівні) та військові мобільні госпіталі, що розгортаються частково чи повністю в польових умовах або на базі цивільних закладів охорони здоров’я.

Військовий мобільний госпіталь $\epsilon$ спеціалізованим, багато профільним, мобільним лікувальним закладом охорони здоровя 3С України, що призначений для надання кваліфікованої та окремих елементів спеціалізованої медичної допомоги пораненим, травмованим, ураженим, хворим військовослужбовцям та цивільним особам, за визначеним рівнем i обсягом 3 подальшою евакуацією за призначенням в лікувальні заклади вищого рівня в умовах мирного часу та особливий період, відповідно до вимог законодавства та положень міжнародного гуманітарного права [9]. Кожний військовий мобільний госпіталь розрахований на надання медичної допомоги пораненим та хворим зі складу 2-3 бригад. Військові мобільні госпіталі передаються в оперативне підпорядкування начальника медичної служби оперативного угруповання військ, що ведуть бойові дії.

За досвідом медичного забезпечення Збройних Сил України та інших військових формувань під час антитерористичної операції (операції об'єднаних сил) цивільні заклади охорони здоров'я залучені до системи лікувальноевакуаційних заходів нарівні 3 військовими 
мобільними госпіталями. Так, у районних (міських) лікарнях, що розташовані в районах проведення бойових дій на території Донецької та Луганської областей, підсилених групами військових лікарів здійснюється прийняття та сортування поранених, проведення діагностичних заходів хірургічної допомоги, проведення реанімаційних i протишокових заходів та тимчасове утримання до евакуації [10].

У подальшому проводиться медична евакуація у стаціонарні військові або цивільні заклади охорони здоров'я, що розташовані в межах операційної зони, зокрема в умовах проведення антитерористичної операції (операції об'єднаних сил) в містах Запоріжжя, Харків та Дніпро (обласна клінічна лікарня імені Мечнікова). На цьому рівні надається кваліфікована i спеціалізована медична допомога(діагностика та необхідне стаціонарне лікування поранених в зоні бойових дій 3 метою їх найшвидшого повернення до строю або направлення на наступний етап евакуації [10].

\section{Висновки й перспективи подальших досліджень}

Досвід організації надання кваліфікованої медичної допомоги в ході антитерористичної

\section{Лimepamypa}

1. Лозовий М.Г. Визначення першочергових напрямків зниження безповоротних втрат особового складу у сучасних збройних конфліктах / Лозовий М.Г., Воробйов О.М., Власов I.О. // Збірник наукових праць Національного університету оборони України імені Івана Черняховського “Труди університету". - 2015. №1(128). - С. 179 - 182. 2. Концепція Програми розвитку системи медичного забезпечення Збройних Сил України на період до2020 року, затвердженої Наказом МОУ 26 липня 2017 року № 389. 3. Постанова Кабінету Міністрів України від 31. 10. 18 № 910 "Про затвердження Воєнно-медичної доктрини України" 4. Розпорядження Кабінету Міністрів України від 24. 05. 17 №352-р “Деяки питання медичного забезпечення військовослужбовців, осіб рядового і начальницького складу та поліцейських, які беруть участь в антитерористичній операції та здійсненні заходів із забезпечення національної безпеки і оборони, відсічі стримування збройної агресії Російської Федерації у Донецькій та Луганській області”. 5. Сохін О.О., Булах операції (операції об'єднаних сил) свідчить про ефективність способу наближення відповідних мобільних медичних груп до військ (сил), що дає можливість суттєвого скорочення часу надання першої лікарської та кваліфікованої допомоги.

Другою тенденцією удосконалення системи лікувально-евакуаційного забезпечення військ за досвідом медичного забезпечення військ (сил) в ході антитерористичної операції (операції об'єднаних сил) є залучення цивільних закладів охорони здоров'я до системи лікувальноевакуаційних заходів нарівні 3 військовими мобільними госпіталями для надання кваліфікованої та елементів спеціалізованої медичної допомоги.

Лікувально-евакуаційні заходи в системі медичного забезпечення військ у бойових умовах за досвідом антитерористичної операції (операції об'єднаних сил), локальних війн і збройних конфліктів концептуально повинні здійснюватися за рівнями медичного забезпечення.

Подальші дослідження доцільно спрямувати на удосконалення порядку залучення системи цивільної охорони здоров'я для надання спеціалізованої та високоспеціалізованої медичної допомоги пораненим військовослужбовцям.

О.Ю., Черней Л.М. Стратегія збереження життя поранених у сучасних війнах та за надзвичайних ситуацій мирного часу // Наука і оборона, - 2006. - №1. с. 44 - 48. 6. В.Л. Савицький, О.М. Власенко, В.І. Стрижено, О. Ю. Булах Система медичного забезпечення військ (сил) - складова загальнодержавної політики охорони здоровя громадян України Наука i оборона 2014 №2. С.27-33. 7. Методичні рекомендації 3 організації роботи цивільних закладів охорони здоровя щодо надання вторинної (спеціалізованої) та третинної (високоспеціалізованої) медичної) допомоги військовослужбовцям Збройних Сил України та інших військових формувань за ред. Хоменка І.П. та Галушки А.М. Київ-2019, 137с. 8. Звіт Департаменту воєнної політики та стратегічного планування Міністерства оборони України від 29 вересня 2014 р. № 230/2/1535. 9. Доктрина "Медичні сили Збройних Сил України". 10. Наказ МОУ від 09. 07. 2018 № 258 Про затвердження Керівництва 3 медичної евакуації у Збройних Силах України.

\title{
ОПЫТ ОРГАНИЗАЦИИ МЕДИЦИНСКОГО ОБЕСПЕЧЕНИЯ ВОЙСЬК (СИЛ) В ОПЕРАЦИИ ОБЪЕДИНЕННЫХ СИЛ
}

\author{
Михаил Григорвевич Лозовой ${ }^{1}$ \\ Олег Михайлович Воробьёв (доктор технических наук, профессор) ${ }^{1}$ \\ Игорь Александрович Власов (кандидат военных наук, доцент) ${ }^{1}$ \\ Николай Николаевич Чапля (кандидат медицинских наук) ${ }^{2}$
}

\begin{abstract}
${ }^{1}$ Национальный университет обороны Украины имени Ивана Черняховского, Киев, Украина ${ }^{2}$ Медицинский реабилитационный центр МВД Украины “Жемчужина Прикарпатья”, Трускавец, Украина

Изучение особенностей работы медицинской службы Вооруженных Сил Украинь по планированию, организаџии и реализации медицинского обеспечения в мирное и военное время 6 различных условиях является приоритетным направлением ее деятельности. В соответствии с требованиями руководящих документов медицинское обеспечение войск (сил) долюно быть организовано в любых условиях действий войск (сил): как при ведении боевых действий, так и в условиях повседневной деятельности. В условиях современной гибридной войны на организацию медицинского обеспечения войск (сил)влияют факторы оперативной, боевой, медицинской и тыловой обстановки, Поэтому, для планирования медицинского обеспечения войск (сил) в операции объединенных сил (OОС) (антитеррористической операции (АТО)) необходимо эти факторы изучить и проанализировать их влияние на организацию медицинского обеспечения. В статье рассматриваются вопросы, касаюшиеся
\end{abstract}


факторов, влияющих на организаџию медицинского обеспечения войсковых частей и соединений, общих принцииов использования сил медицинской службь в ООС (АТО), особенностей их использования в разные периоды операщий.

Целью данной статьи является изучение условий деятельности медищинской службы, общих принципов и способов использования сил и средств медиџинской службы ВС Украины во время проведения ООС. Авторы рассматривают порядок (варианты) использования приемов сокращения времени оказания первой врачебной, квалифицированной и специализированной медицинской помощии путем создания новых медииинских формирований (подразделений), которые ранее не предусматривались, а также интеграционными процессами в систему гражданской системь здравоохранения. Определяется, что указанные пути использования сил и средств медицинской службы как ВС Украины, так и МЗО Украинь существенно сокращзают сроки оказания первой врачебной, квалифицированной и специализированной медицинской помощии военнослужащим ВС Украины.

Ключевые слова: медицинское обеспечение, лечебно-эвакуационные мероприятия, вид медицинской помощи, военный подвижный госпиталь, гражданское здравоохранение, квалифицированная медицинская помощь.

\title{
EXPERIENCE OF ORGANIZATION OF MEDICAL SUPPORT OF TROOPS (FORCES)
} IN THE OPERATION OF THE JOINT FORCES

\author{
Mykhaylo Lozovuy ${ }^{1}$ \\ Oleh Vorobiov (Doctor of Technical Sciences, Professor) ${ }^{1}$, \\ Ihor Vlasov (Candidate of Military Sciences, Associate Professor) ${ }^{1}$ \\ Mykola Chaplia (Candidate of Medical Sciences) ${ }^{2}$
}

\author{
${ }^{1}$ National Defence University of Ukraine named after Ivan Cherniakhovskyi, Kyiv, Ukraine \\ ${ }^{2}$ Medical Rehabilitation Center of the Ministry of Internal Affairs of Ukraine "Zhemchuzhina Prykarpattya", \\ Truskavets, Ukraine
}

Studying the peculiarities of the work of the medical service of the Armed Forces of Ukraine on the planning, organization and implementation of medical care in peacetime and wartime in various conditions is a priority of its activities. According to the requirements of the guiding documents, medical support of troops (forces) must be organized in any conditions of activity of troops (forces): both in combat operations and in the conditions of daily activities of troops.) In modern hybrid warfare ) are influenced by factors of operational, combat, medical and logistical conditions. Therefore, in order to plan the medical support of troops (forces) in the Joint Forces Operation (ATO), it is necessary to study these factors, analyze their impact on the organization of medical support, draw conclusions and make decisions on the organization of medical support. The article considers the issues related to the factors influencing the organization of medical support of military units and formations, the general principles of the use of medical services in the JFO (ATO), the peculiarities of their use in different periods of the operation.

The purpose of this article is to study the conditions of the medical service during the ATO (JFO), the general principles and methods of using the forces and means of the medical service of the Armed Forces of Ukraine during the operation (JFO). The authors consider the procedure (options) for using time reduction techniques to provide first aid, qualified and specialized medical care by creating new medical units (units), which were not previously provided, as well as integration processes into the civil health system. forces and means of medical service of both the Ministry of Defense of Ukraine and the Ministry of Health of Ukraine significantly reduce the time of providing first medical, qualified and specialized medical care to servicemen of the Armed Forces of Ukraine.

Key words: medical support, medical and evacuation measures, type of medical care, military mobile hospital, civilian health care, qualified medical care.

\section{References}

1. Lozovuy M.G. Determination of priority areas for reducing irreversible losses of personnel in modern armed conflicts / Lozovuy M.G., Vorobyov O.M., Vlasov I.O. // Collection of scientific works of the Ivan Chernyakhovsky National University of Defense of Ukraine "Proceedings of the University". - 2015. - №1 (128). - P. 179 - 182. 2. Concept of the Program of development of the medical support system of the Armed Forces of Ukraine for the period up to 2020, approved by the Order of the Ministry of Internal Affairs on July 26, 2017 № 389. 3. Resolution of the Cabinet of Ministers of Ukraine dated 31. 10. 18 № 910 "On approval Military Medical Doctrine of Ukraine". 4. Order of the Cabinet of Ministers of Ukraine dated 24. 05. 17 №352-r "Some issues of medical care for servicemen, privates and officers and police officers involved in the antiterrorist operation and the implementation of measures to ensure national security and defense, repulse and deterrence armed aggression of the Russian Federation in Donetsk and Luhansk regions ". 5. Sokhin O.O., Bulakh O.Y., Cherney
L.M. Strategy for saving the lives of the wounded in modern wars and in peacetime emergencies // Science and Defense, 2006. - №1. - with. 44 - 48. 6. V.L. Savitsky, O.M. Vlasenko, V.I. Stryzheno, O.Y. Bulakh The system of medical support of troops (forces) is a component of the national policy of health protection of citizens of Ukraine Science and Defense 2014 №2. P.27-33. 7. Methodical recommendations on the organization of work of civilian health care institutions on the provision of secondary (specialized) and tertiary (highly specialized) medical care to servicemen of the Armed Forces of Ukraine and other military formations, ed. Khomenko I.P. and Galushki A.M. Kyiv-2019, 137p. 8. Report of the Department of Military Policy and Strategic Planning of the Ministry of Defense of Ukraine dated September 29, 2014 № 230/2/1535. 9. Doctrine "Medical Forces of the Armed Forces of Ukraine". 10. Order of the Ministry of Internal Affairs of 09. 07. 2018 № 258 On approval of the Manual on medical evacuation in the Armed Forces of Ukraine. 